INTERNATIONAL JOURNAL OF RESEARCHES IN BIOSCIENCES, AGRICULTURE AND TECHNOLOGY

(c) VISHWASHANTI MULTIPURPOSE SOCIETY (Global Peace Multipurpose Society) R. No. MH-659/13(N) www.ijrbat.in

\title{
ELECTRONIC DATABASE OF SOCIO-ECONOMICALLY IMPORTANT PLANTS OF WARDHA DISTRICT
}

\author{
I. P. Ramteke and T. Srinivasu \\ Post Graduate Department of Botany, Rashtrasant Tukadoji Maharaj Nagpur University, \\ Nagpur-440033, Maharashtra, India \\ ishaaramteke.22@gmail.com
}

\begin{abstract}
:
Socio-economically important plants are useful in many ways i.e. directly as food or indirectly as products. Plants provide us food, fodder, fiber, fuel, flowers for ornamental use, for religious and celebration purpose, raw materials for many industries including pharmaceuticals, timber for construction etc. The present study was conducted to explore plant diversity during 2013 to 2017 at various parts of eight talukas of Wardha district in Vidarbha (Maharashtra). In this study, the data collected from different localities of the district shows 760 dicot species which belongs to 106 families. Out of these, most of the plants are socio-economically important. This data was fed in the DELTA (Descriptive Language for Taxonomy) package (Dallwitz, et al., 2000) and prepared electronic database of Wardha district. The characters used to describe various plant parts such as habit, root, stem, leaf, flower, fruits, seeds etc. and noted various uses such as medicinal, dye, tannin, fodder, avenue, spices and condiments, ornamental, timber, cultivation for its flower, fiber, oil, pulses, fruit vegetables, leafy vegetables, border and fence, sacred etc. Additional information of plant species were also incorporated along with family, botanical names, synonyms and references, full morphological descriptions, common and vernacular names, flowering and fruit duration, location, status of the plants in nature and digital photographs (Ramteke and Srinivasu 2016). This electronic database is useful for identification of plant species with their economic uses and several other for rural developmental and welfare programs.
\end{abstract}

Keywords: Vidarbha (Maharashtra), dye, tannin, fodder, avenue, spices and condiments, ornamental, timber.

\section{INTRODUCTION:}

A database is an organized collection of data (https://www.britannica.com/technology/database) Databases are created to operate large quantities of information by inputting, storing, retrieving, and managing that information through software programs, which provides information of all the data in different ways to all users. In other words it is a computer-based collection or listing of information, usually organized with searchable elements or fields. Flora is Collection of information of the plants of a particular region, habitat, or geological period. If this information is presented in electronic format then it is called 'electronic database'. Electronic database of Wardha district shows 760 dicot plant species belongs to 106 families and 445 genera. This database provides us the socio-economic importance of plants such as fodder plants, oilseed plants, tannin yielding plants, ornamental plants, vegetable plants etc. This type of work was also carried out in Mumbai, Nagpur and Chandrapur. This database helps us in accurate and faster identification of plant species with their location and socio-economical values of that region along with plant descriptions. Electronic database is a collection of economic plant data arranged in a systematic way to make the search easy and fast.
Hence, it is thought worthwhile to study and prepare electronic database of Wardha district.

DELTA package has several advantages such as

- It is a permanent database with digital images which helps to retained original colours of plants.

- It is eco-friendly.

- This database can be updated regularly.

- It requires minimal maintenance.

- Digital herbarium easily accessible.

- Very large information of plants can be stored digitally in a small space of computer.

- No biodegradation.

- Prevent from pathogenic or insect attack etc.

This new method is well accepted technique in Europe, America, Australia and even in India. Other important information such as botanical name, family, synonyms, full description such as habit, habitat, phyllotaxis, inflorescence type, flowering and fruiting description, status of the plant in the nature, common and vernacular name, economical and medicinal values of plants, and distribution in Wardha district along with digital images of respectively plants etc. added to the electronic database for further applications. 


\section{METHOD AND MATERIAL:}

The socio-economically important plants of Wardha district was explored in all seasons for four years (2013-2017). During the study period several field trips were undertaken including visits to water bodies, cultivated lands, gardens, road sides and forest area etc. Plants collected during flowering and fruiting period for accurate identification of specimen. Digital photos were taken in their natural habitat with flowering and fruiting stage to complete preparation of database. The data was prepared and analyzed in the laboratory with the help of available literature (Ramteke and Srinivasu 2016).

\section{RESULT AND DISCUSSION:}

The present study was clear that large number of species, which are used for various purposes such as food, vegetable, fodder, fibers, timber, oil etc. They can be broadly classified into medicinal plants, ornamental plants, avenue plants, edible fruits, fruit vegetables, leafy vegetables, fiber yielding plants, oil-producing plants, timber plants etc. The details of each category of plants are given below.

Some Medicinal plants areAzadirachta indica A. Juss., Centellaasiatica (L.) Urban, Tridax procumbens L., Catharanthus roseus (L.) G. Don., Rauvolfia serpentine Benth. Ex Kurz,Withania somnifera (L.) Dunal., Bacopamonnieri (L.) Wettst., Andrographis paniculata (Burm. f.) Nees, Justicia adhatoda L., Ocimum tenuiflorum L., Santalum album L., etc.

Ornamental plants are Polyalthia longifolia (Sonn.) Thwaites., Viola tricolor L., AlcearoseaL., Bauhinia tomentosaL., Rosa canina L., Aster amellus L., Chrysanthemum indicum L., Cascabella thevetia (L.) Lippold, Tabernaemontana citrifolia L. etc.

Avenue plants are Kigeliaafricana (Lam.) Benth., Bauhinia purpurea L., B. variegate L., Delonixregia (Hook.) Raf., Albizialebbeck (L.) Benth.var. lebbeck, Bombax ceiba L.etc.

Timber yielding plants are Tectona grandis L. f., Santalum album L. Gmelina arborea Roxb., Ailanthus excels Roxb.etc.

Fodder plants are Stylosanthes fruticosa (Retz.) Alston, Alysicarpus longifolius (Spreng.)Wight \& Arn., Alysicarpus scariosus (Spreng.) Thwaites. Crotalaria medicaginea Lam., Cyamopsis tetragonoloba (L.) Taub., Desmodium triflorum (L.) DC., Medicago polymorpha L., Melilotus alba Medik., Vigna trilobata (L.) Verdc.var. trilobata, Mimosa hamata Willd. etc.
Edible fruits are Tamarindus indica L., Annona squamosa L., Citrus aurantii folia (Christm.) Swingle, C. sinensis (L.) Osbeck, Limonia acidissima Groff, Ziziphus mauritiana Lam., Z. oenopoila (L.) Mill., Morus alba L. etc.

Some Border and fence plant are Argyreia nervosa (Burm. f.) Bojer, Ipomoea cairica (L.) Sweet. I. quamoclit L. etc.

Fruit vegetables plants are Lycopersicon lycopersicum (L.) Karsten., Solanum melongena L., Abelmoschus esculentus (L.) Moench, Artocarpus heterophyllus Lam. etc.

Sacred plants are Ocimum tenuiflorum L., Ficus bengalensis L., F. religiosa L., Aeglemar melos(L.) Correa, etc.

Pulses plants are Cajanus cajan (L.) Millsp., Vigna aconitifolia (Jacq.) Marechal, V. mungo(L.)Hepper, $V$. radiate (L.) R. Wilczek etc.

Leafy vegetables are Trigonella foenum-graecum L., Amaranthus cruentus L., Spinacia oleracea L., Hibiscus sabdariffa L., Lathyrus sativus L., Trigonellafoenum-graecum L. etc.

Dye yielding plants are Bixa orellana L., Rivina humilis L., Butea monosperma (Lam.) Taub., Indigofera tinctoria L., Lawsonia inermis L. Morinda pubescens Sm. etc.

Oil seeds are Helianthus annuus L., Ricinus communis L.,Sesamum indicum L., Brassica juncea (L.) Czern., B. nigra (L.) K. Koch, Linum usitatissimum L. etc.

Fruit Pickle plants are Carissa carandas L., Citrus aurantiifolia (Christm.) Swingle, Citrus limon (L.) Osbeck, Phyllanthus emblicaL. etc.

Tannin yielding plants are Acacia auriculiformis A. Cunn. Ex Benth. Lond., Parkia biglandulosa Wight $\&$ Arn.Terminalia elliptica Willd. etc.

\section{CONCLUSION}

This database includes many plants, which are economically important and socially useful to mankind in several ways. In this study, these important plant species were identified which provide significant economic, social and ecological values which are of fundamentally important for livelihood of rural folk. This digital database provides us existing plant information and ensure that local communities will certainly use the contribution of this database in future as readymade reference. It is also useful that numerous wild plants which are now available and in use gives insight for high potentiality for regional economic development. Further, this database helps 
to identify rare and important species to develop suitable methods for propagation and production. Cultivation of those species not only fulfils the domestic and commercial demand but also to provide insight for conservation of these wild, important and rare species. Therefore, an urgent need to develop this kind of databases in every district to show the current status of the plant in nature, inclination to manage, conserve, protect and utilise our plant resources properly and subsequently to develop and uplift the tribal and rural communities' income.

\section{ACKNOWLEDGEMENT}

One of the authors is thankful to Head of the Department, PGTD of Botany, Rashtrasant Tukadoji Maharaj Nagpur University, Nagpur for providing facilities in the laboratory.

\section{REFERANCE :}

Dallwitz, M. J., Paine, T. A. \& Zurcher, E. J. (2000) User's Guide to the DELTA System: a General System for Processing Taxonomic Descriptions. $4^{\text {thedi. }}$

https://www.britannica.com/technology/database.

Ramteke, I. P. and Srinivasu, T., Some woody dicot plants diversity of Wardha, Karanja and SelooTalukas. Int. J. of Life Sciences, Special Issue A6: 111-113, (2016).

Ramteke, I. P. \&Srinivasu, T., Electronic Database Of Some Medicinal Plants Of Wardha District. Indian J. Sci. Res. 13 (2): 6-8, (2017).

Srinivasu, T. Electronic Herbarium and Digital Flora of Mumbai.Proc. of $2^{\text {nd }}$ NATWED, 20-24, (2005).

\begin{tabular}{|c|c|c|c|}
\hline $\begin{array}{l}\text { Medicinal } \\
\text { plants }\end{array}$ & 440 species & $\begin{array}{l}\text { Leafy } \\
\text { vegetables }\end{array}$ & 15 species \\
\hline $\begin{array}{l}\text { Ornamental } \\
\text { plants }\end{array}$ & 183 species & $\begin{array}{l}\text { Dye yielding } \\
\text { plants }\end{array}$ & 12 species \\
\hline Avenue plants & 43 species & Oil seeds & 11 species \\
\hline $\begin{array}{l}\text { Timber } \\
\text { yielding } \\
\text { plants }\end{array}$ & 36 species & $\begin{array}{l}\text { Fiber } \\
\text { yielding }\end{array}$ & 7 species \\
\hline Fodder plants & 30 species & $\begin{array}{l}\text { Gum and } \\
\text { resin } \\
\text { yielding } \\
\text { plants }\end{array}$ & 7 species \\
\hline $\begin{array}{l}\text { Edible fruits } \\
\text { plants }\end{array}$ & 28 species & $\begin{array}{l}\text { Seeds edible } \\
\text { plant }\end{array}$ & 6 species \\
\hline $\begin{array}{l}\text { Border and } \\
\text { fence plant }\end{array}$ & 21 species & $\begin{array}{l}\text { Fruit Pickle } \\
\text { plants }\end{array}$ & 5 species \\
\hline $\begin{array}{l}\text { Fruit } \\
\text { vegetables }\end{array}$ & 19 species & $\begin{array}{l}\text { Tannin } \\
\text { yielding } \\
\text { plants }\end{array}$ & 4 species \\
\hline $\begin{array}{l}\text { Flowers for } \\
\text { aesthetics } \\
\text { and } \\
\text { celebration }\end{array}$ & 19 species & $\begin{array}{l}\text { Spices and } \\
\text { Condiments }\end{array}$ & 4 species \\
\hline Sacred plants & 19 species & Roots edible & 3 species \\
\hline Pulses plants & 8 species & $\begin{array}{l}\text { Liquor } \\
\text { yielding } \\
\text { plants }\end{array}$ & 2 species \\
\hline
\end{tabular}

Table: Some Socio-economical important Plants 
